Case Reports
in Dermatology
Case Rep Dermatol 2020;12:186-191

DOI: $10.1159 / 000509992$

Published online: October 30, 2020 (c) 2020 The Author(s)

Published by S. Karger AG, Basel www.karger.com/cde

This article is licensed under the Creative Commons Attribution-NonCommercial 4.0 International License (CC BY-NC) (http://www.karger.com/Services/OpenAccessLicense). Usage and distribution for commercial purposes requires written permission.

\title{
Schimmelpenning Syndrome with Large Nevus Sebaceous and Multiple Epidermal Nevi
}

\author{
Reiva Farah Dwiyana Maryam Nissa Hazari Inne Arline Diana \\ Srie Prihianti Gondokaryono Raden Mohamad Rendy Ariezal Effendi \\ Hendra Gunawan
}

Department of Dermatology and Venereology, Faculty of Medicine, Universitas Padjadjaran - Hasan Sadikin General Hospital, Bandung, Indonesia

\section{Keywords}

Epidermal nevus syndrome $\cdot$ Nevus sebaceous $\cdot$ Schimmelpenning syndrome

\begin{abstract}
Epidermal nevus syndromes are a group of rare multiorgan disorders. Schimmelpenning syndrome is a clinical variant of epidermal nevus syndromes. This congenital syndrome is characterized by the existence of nevus sebaceous and usually accompanied by abnormalities of the eyes, skeletal, cardiovascular, and central nervous systems. A 2-year-old girl presented with large, hairless, yellowish-brown plaques on the scalp and face along with multiple brownishblack verrucose plaques and brownish-black macules on almost all parts of the body. The skincolored verrucose tumors were also found on the lips and around the mouth. Histopathological examination of the lesion on the forehead revealed hyperkeratosis, acanthosis, and sebaceous gland hyperplasia supporting the diagnosis of nevus sebaceous, while histopathological examination of the lesions on the lips and abdomen demonstrated hyperkeratosis, acanthosis, and papillomatosis consistent with verrucous epidermal nevus. The pediatrician suspected that the patient had mental retardation; however, there were no neurological, cardiac, skeletal, nor ophthalmologic abnormalities. The lesions on the lips and around the mouth were excised, and it demonstrated a good result. To conclude, epidermal nevus syndrome (e.g., Schimmelpenning syndrome) should be considered in children born with nevus sebaceous.
\end{abstract}




\section{Case Reports in Dermatology}

\begin{tabular}{l|l}
\hline DOI: 10.1159/000509992 & $\begin{array}{l}\text { (c) } 2020 \text { The Author(s). Published by S. Karger AG, Basel } \\
\text { www.karger.com/cde }\end{array}$ \\
\hline
\end{tabular}

Dwiyana et al:: Schimmelpenning Syndrome with Large Nevus Sebaceous and Multiple Epidermal Nevi

\section{Introduction}

Schimmelpenning syndrome is a variant of epidermal nevus syndromes, characterized by one or several nevus sebaceous with abnormalities of ocular, cardiac, skeletal, and nervous systems $[1,2]$. The occurrence of this syndrome is very rare. It occurs sporadically and affects both genders [2]. Nevus sebaceous, the hallmark of Schimmelpenning syndrome, is a hamartoma of the epidermal, follicular, sebaceous, and apocrine elements, with sebaceous glands as a predominant element. The scalp is the predilection of nevus sebaceous, followed by the face. This nevus has also been identified on the preauricular area, neck, and locations far from the head and neck $[3,4]$. Neurological abnormalities in Schimmelpenning syndrome include mental retardation, seizures, hemiparesis, and structural abnormality of the cerebrum and cranium [5, 6]. This case report aims to demonstrate a rare case of Schimmelpenning syndrome with a large nevus sebaceous on the scalp and face along with multiple epidermal nevi on almost all parts of the body.

\section{Case Presentation}

A 2-year-old girl presented with yellowish-brown plaques on the head along with brown plaques and brown macules on almost all parts of the body since birth. New skin lesions appeared as verrucose, brown tumors on the lips and around the mouth in the last 5 months prior to visit. She was born to a G1P0 healthy mother via normal spontaneous vaginal delivery at a gestational age of 38 weeks with normal birth weight. Physical examination was normal without any neurological abnormalities. Large, hairless, yellowish-brown plaques were found on the scalp and face (Fig. 1a), accompanied by brownish-black, verrucose plaques and brownish-black macules on the trunk and extremities following the Blaschko line (Fig. 1b). The skin-colored verrucose tumors were also found on the lips and around the mouth (Fig. 1c). Histopathological examination of the plaque lesions on the forehead revealed hyperkeratosis, acanthosis, and sebaceous gland hyperplasia, while histopathological examination of the plaque lesions on the lips and abdomen showed hyperkeratosis, acanthosis, and papillomatosis (Fig. 2). These histopathological findings supported the diagnosis of nevus sebaceous on the forehead and verrucous epidermal nevus on the lips and abdomen. The patient was also evaluated with a multidisciplinary approach to identify any abnormalities associated with the epidermal nevus syndromes. The Growth and Development Division of the Pediatric Department diagnosed the patient with suspected mental retardation. In addition, the Cardiology Division of the Pediatric Department found no abnormalities in the cardiovascular system, which was proven by electrocardiography, echocardiography, and chest X-ray findings. The neurologist found no neurological deficit with no abnormalities on the computed tomography scanning of the head. Neither skeletal deformities nor ophthalmic abnormalities were found upon examination by the Orthopedic and Ophthalmology Department, respectively. Therefore, the diagnosis of Schimmelpenning syndrome was established. The lesion on the lips and around the mouth were excised by a plastic surgeon, and it showed a good result. The patient is still observed for additional symptoms of Schimmelpenning syndrome. 


\section{Case Reports in Dermatology}

Case Rep Dermatol 2020;12:186-191

DOI: 10.1159/000509992

(C) 2020 The Author(s). Published by S. Karger AG, Basel www.karger.com/cde

Dwiyana et al.: Schimmelpenning Syndrome with Large Nevus Sebaceous and Multiple Epidermal Nevi

\section{Discussion and Conclusion}

Epidermal nevus syndromes are a group of distinct disorders, characterized by the presence of epidermal nevus in association with various developmental abnormalities of the skin, eyes, nervous, skeletal, cardiovascular, and urogenital systems [2, 7]. Most epidermal nevi are present at birth and frequently follow the Blaschko line [2]. There are nine epidermal nevus syndromes that are well-defined by clinical, histopathological, and genetic criteria [7]. Schimmelpenning syndrome is a well-known variant of the epidermal nevus syndrome [4]. The cause of Schimmelpenning syndrome has not been elucidated, but it has been hypothesized to result from genomic mosaicism. [8] This syndrome is uncommon, occurring sporadically with a female-to-male ratio of 1:1 [2].

Schimmelpenning syndrome is a congenital neurocutaneous disorder encompassing the cutaneous nevi (nevus sebaceous of Jadassohn) in conjunction with extracutaneous (neurologic, skeletal, cardiovascular, ophthalmic, and urologic) abnormalities. Nevus sebaceous is a hallmark of Schimmelpenning syndrome. If the physicians are aware of this distinct skin lesion, the diagnosis can be established early. In a review of nevus sebaceous patients, the scalp was found to be the most common location (59.3\%), followed by the face $(32.6 \%)[3,4]$. To date, there are very few reports of Schimmelpenning syndrome. Wang et al. [4] and Greene et al. [9] reported cases of the Schimmelpenning syndrome with nevus sebaceous alone as the cutaneous manifestation [9]. A case of the Schimmelpenning syndrome reported by Joshi et al. [10] demonstrated nevus sebaceous and giant melanocytic nevi as cutaneous manifestations. In this case report, a girl was diagnosed with a Schimmelpenning syndrome with clinical manifestations of a large nevus sebaceous on the scalp and face along with multiple epidermal nevi on almost all parts of the body, which has never been reported before.

In Schimmelpenning syndrome, neurologic findings are identified in $66 \%$ of the cases with major abnormalities; e.g., mental retardation, seizures, hemiparesis, lateral ventricle enlargement, complete or partial hemimegalencephaly [11,12]. Ophthalmological abnormalities are present in 59\% of the cases with major abnormalities; e.g., colobomas and choristomas [13]. Cardiovascular abnormalities that can be identified in this syndrome are patent ductus arteriosus, patent foramen ovale, ventricular septal defect, coarctation of the aorta, hypoplasia of the aorta, arterial flutter/fibrillation, and arterial premature systoles [14]. Hypophosphatemic rickets (vitamin D-resistant rickets) has been described in several cases of Schimmelpenning syndrome $[12,15]$. This condition is characterized by bone deformations and growth retardation in childhood [12]. In this case, the patient was suspected to have mental retardation without any neurological, cardiac, skeletal, and ophthalmologic abnormalities.

There is no ideal treatment for the cutaneous lesions of epidermal nevus syndromes. The skin lesion can be treated with surgery. Sometimes, it responds to topical salicylic acid, topical and systemic retinoids, topical vitamin D analogue, laser treatment, shave dermabrasion, or cryotherapy. Emollients, such as hydrated petrolatum, vaseline, or mineral oil, have also been used. Evaluation of child growth and development as well as multiorgan involvement might be important for long-term observation of the patient [2]. In this case, surgical excision was performed on the epidermal nevus with good result, and multiorgan involvement is still observed.

In conclusion, epidermal nevus syndromes should be considered in children born with nevus sebaceous. Schimmelpenning syndrome is associated with a wide range of abnormalities, and careful evaluation of multiorgan involvement is necessary. 


\section{Case Reports in Dermatology}

\begin{tabular}{l|l}
\hline DOI: $10.1159 / 000509992$ & (c) 2020 The Author(s). Published by S. Karger AG, Basel
\end{tabular}
www.karger.com/cde

Dwiyana et al.: Schimmelpenning Syndrome with Large Nevus Sebaceous and Multiple Epidermal Nevi

\section{Acknowledgements}

The authors would like to thank all staff of the Dermatology and Venereology Department, Faculty of Medicine, Universitas Padjadjaran - Hasan Sadikin General Hospital.

\section{Statement of Ethics}

The authors have obtained the parents' written informed consent for publication (including the image) of their daughter's case. This study was conducted ethically in accordance with the World Medical Association Declaration of Helsinki.

\section{Conflict of Interest Statement}

The authors have no conflicts of interest to declare.

\section{Funding Sources}

The authors have no funding sources to declare.

\section{Author Contributions}

R.F.D., M.N.H., I.A.D., S.P.G., and R.M.R.A.E., contributed to the analysis of the medical report and interpretation of data. R.F.D., M.N.H., and H.G., contributed to drafting the article and reviewing it critically for significant intellectual content. H.G. gave the final approval of the version to be submitted and any revised version.

\section{References}

1 Swanson NA, Lee KK. Benign Epithelial Tumors, Hamartomas, and Hyperplasias. In: Wolf K, Goldsmith LA, Katz SI, Gilchrest BA, Paller AS, Leffel DJ, editors. Fitzpatrick's dermatology in general medicine. 8th ed. New York: McGrawHill; 2012. pp. 1319-36.

2 Stavrianeas NG, Kakepis ME. Epidermal nevus syndrome. Orphanet Encyclopedia; 2014. pp. 1-4.

3 Jaqueti G, Requena L, Sánchez Yus E. Trichoblastoma is the most common neoplasm developed in nevus sebaceus of Jadassohn: a clinicopathologic study of a series of 155 cases. Am J Dermatopathol. 2000 Apr;22(2):108-18.

4 Wang SM, Hsieh YJ, Chang KM, Tsai HL, Chen CP. Schimmelpenning syndrome: a case report and literature review. Pediatr Neonatol. 2014 Dec;55(6):487-90.

5 van de Warrenburg BP, van Gulik S, Renier WO, Lammens M, Doelman JC. The linear naevus sebaceus syndrome. Clin Neurol Neurosurg. 1998 Jun;100(2):126-32.

6 Lovejoy FH Jr, Boyle WE Jr. Linear nevus sebaceous syndrome: report of two cases and a review of the literature. Pediatrics. 1973 Sep;52(3):382-7.

7 Feuerstein RC, Mims LC. Linear nevus sebaceus with convulsions and mental retardation. Am J Dis Child. 1962 Dec;104:675-9.

8 Carlson JA, Cribier B, Nuovo G, Rohwedder A. Epidermodysplasia verruciformis-associated and genitalmucosal high-risk human papillomavirus DNA are prevalent in nevus sebaceus of Jadassohn. J Am Acad Dermatol. 2008 Aug;59(2):279-94.

9 Greene AK, Rogers GF, Mulliken JB. Schimmelpenning syndrome: an association with vascular anomalies. Cleft Palate Craniofac J. 2007 Mar;44(2):208-15. 


\section{Case Reports in Dermatology}

\begin{tabular}{l|l}
\hline Case Rep Dermatol 2020;12:186-191 \\
\hline DOI: 10.1159/000509992 & $\begin{array}{l}\text { @ 2020 The Author(s). Published by S. Karger AG, Basel } \\
\text { www.karger.com/cde }\end{array}$ \\
\hline
\end{tabular}

Dwiyana et al.: Schimmelpenning Syndrome with Large Nevus Sebaceous and Multiple Epidermal Nevi

10 Joshi A, Agrawal S, Singh K, Sah SP, Ahrawalla A, Takur SK, et al. Schimmelpenning syndrome (Epidermal Nevus Syndrome): A case report. GJDV. 2012;19(1):61-7.

11 Levin S, Robinson RO, Aicardi J, Hoare RD. Computed tomography appearances in the linear sebaceous naevus syndrome. Neuroradiology. 1984;26(6):469-72.

12 Zutt M, Strutz F, Happle R, Habenicht EM, Emmert S, Haenssle HA, et al. Schimmelpenning-Feuerstein-Mims syndrome with hypophosphatemic rickets. Dermatology. 2003;207(1):72-6.

13 Insler MS, Davlin L. Ocular findings in linear sebaceous naevus syndrome. Br J Ophthalmol. 1987 Apr;71(4):268-72.

14 Eisen DB, Michael DJ. Sebaceous lesions and their associated syndromes: part II. J Am Acad Dermatol. 2009 Oct;61(4):563-78.

15 Kumar GA, Singh A, Singh K. Linear Nevus Sebaceous with Vitamin D3 Resistant Rickets (Schimmelpenning Syndrome). Int J Contemp Med Res. 2017;4(3):1027-8.

a
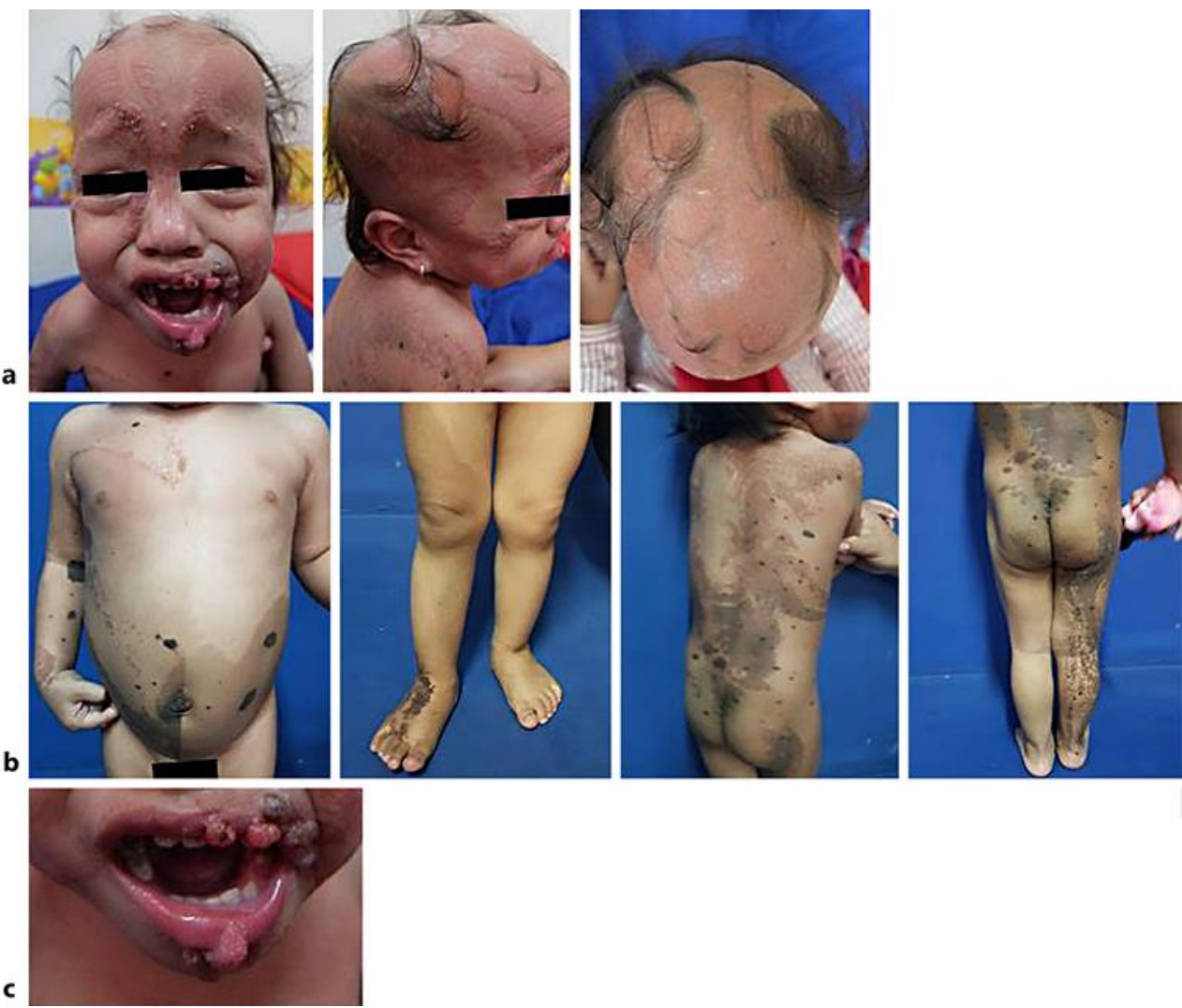

Fig. 1. Cutaneous manifestations of Schimmelpenning syndrome. Nevus sebaceous on the scalp and face (a), epidermal nevi on the trunk and extremities (b), and verrucous epidermal nevi on the lips (c). 


\section{Case Reports in Dermatology} www.karger.com/cde

Dwiyana et al.: Schimmelpenning Syndrome with Large Nevus Sebaceous and Multiple Epidermal Nevi
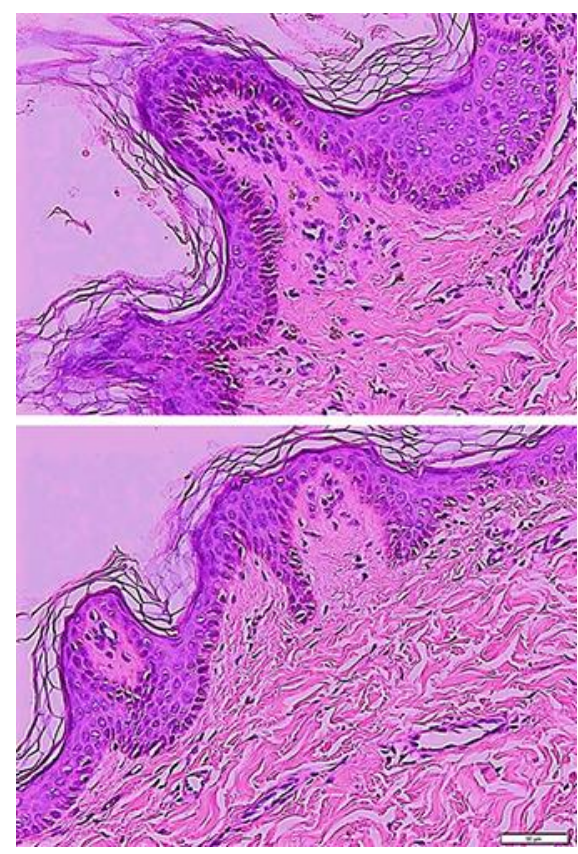

Fig. 2. Histopathological examination of the plaque lesions on the lips and abdomen revealed hyperkeratosis, acanthosis, and papillomatosis (hematoxylin-eosin staining. $\times 100$ ). 